\title{
Effect of Moisture Content on the Mechanical Oil Extraction of Canola Seeds
}

\author{
Gagandeep Singh, A.K. Singh and Pawanpreet Singh* \\ Department of Processing and Food Engineering, Punjab Agricultural University, \\ Ludhiana, India \\ *Corresponding author
}

\section{Keyw ords \\ Canola Seeds, Oil expression, \\ Moisture content, Heating time, Heating temperature \\ Article Info \\ Accepted: \\ 10 February 2019 \\ Available Online: \\ 10 March 2019}

\section{A B S T R A C T}

The experiments were carried out with the objectives to study the effect of moisture content on mechanical characteristics i.e. force required to rupture seed and determining the operational parameters for better recovery of oil from Canola seeds. The experiments were designed using response surface methodology for making various combinations of moisture content $(8.4,12.2,16$ and $20 \%$ w.b.), heating time $(4,8,12$ and 16 mins), heating temperature $\left(70,80,90\right.$ and $\left.100^{\circ} \mathrm{C}\right)$ and steaming time $(5,10,15$ and 20 mins) and the experiments were conducted using single chamber oil expeller. The quality of oil was determined using acid number, iodine value and peroxide value. The effect of moisture content along with heating time and heating temperature on oil recovery were found significant however the effect of the independent variables on residual oil in cake was found non-significant The oil extracted from seeds having $8.4 \%$ moisture content on wet basis was considered to be of good quality. The maximum extraction efficiencies of $91.66 \%$ were observed at $5.81 \%$ moisture content.

\section{Introduction}

Edible oil is the main source of fat in the diet. India is one of the largest producers of oilseeds in the world and this sector occupies an important position in the agricultural economy and accounting for the estimated production of 28.21 million tonnes of nine cultivated oilseeds during the year 2007-08. India contributes about $6-7 \%$ of the world oilseeds production. Export of oil meals, oilseeds and minor oils has increased from 5.06 million tonnes in the year 2005 to 7.3 million tonnes in the year 2006. In terms of value, realization has gone up from Rs. 5514 crores to Rs.7997 crores. India accounted for about 6.4 per cent of world oil meal export (fcamin.nic.in).

Mechanical screw pressing is the most popular method of oil separation from vegetable oilseeds in the world (Mrema and McNulty, 1985). Nearly $90 \%$ of the total oilseeds produced in India are crushed employing this method. Mechanical Extraction is defined as exposure to heat and pressure as a means of extracting oil from the seeds. Oil is extracted by mechanical pressing and extracting with volatile solvents, employed in large scale operations for a more 
complete extraction. The mechanical screw presses (oil expellers) used in India are, however, inefficient as they leave 8 to $14 \%$ of the residual oil in the cake (Srikantha, 1980) and thus, a large quantity of precious edible oil (about 0.6 million tonnes) goes into the deoiled cake. An improvement in the mechanical extraction equipment and techniques through proper conditioning can raise oil recovery from 73 to $80 \%$ in rapeseed and groundnut and from 60 to $65 \%$ in cottonseeds (Pathak et al, 1988).

Canola (Brassica NapusL.) is one of the two cultivars of rapeseed or (Brassica CompestrisL.). The main varieties cultivated in Punjab are GSC-5, GSC-6, Hyola PAC401. Canola seeds are used to produce edible oil that is fit for human consumption because it has lower levels of erucic acid $(<2.5 \%)$ than traditional rapeseed oils and to produce livestock feed. Due to these qualities, canola oil can go a long way in improving the nutritional status of predominantly vegetarian population of the country.

Oil is extracted by different methods like supercritical $\mathrm{CO}_{2}$ and hexane extraction by steam and solvent but these technologies are proved to be more expensive and require more labour and high investment.

The mechanical expression of oil from oilseeds is done at a very large scale and studies on enhancing the oil recovery from oilseeds have been carried out by various workers (Sivakumaran and Goodrum, 1987; Vadke and Sosulki, 1988; Akinso and Igbeka, 2008; Boutin and Badens, 2009) but such studies are lacking for the GSC-5 variety of Canola seeds hence the present studies were planned with the following objectives to study the effect of moisture content, heating time on the oil recovery, residual oil in cake, residual oil in meal.

\section{Materials and Methods}

\section{Small screw expeller}

Single chamber oil expeller (Komet, IBG Monforts, Germany) was used which operates on gentle mechanical press principle that does not involve mixing and tearing of seeds. Table 1 lists some of the specifications of the oil expeller used in the study.

\section{Electrical heater}

This was used to heat up the barrel during the different heat treatments given to the expeller. The heater is made up of copper metal and was housed onto the heating zone. The maximum temperature of the heater recorded was $150-160^{\circ} \mathrm{C}$.

\section{Digital temperature controller}

This was used to measure the temperature of the heater as shown in Figure 1. A thermostat was attached on the oil outlet holes of the barrel to cut off the power supply and to maintain the desired temperature inside the barrel. The thermostat reading is directly recorded on the digital temperature controller. The temperature of the thermostat was adjusted from the knob of the controller.

\section{Canola seeds}

The Canola seeds were purchased from the seeds Department, Punjab Agricultural University, Ludhiana. The GSC-5 variety seeds, having $85 \%$ germination and $98 \%$ purity were used for the experiment and initial moisture content of seeds was measured by standard air oven method (A.S.A.E. 1975). The seeds were kept in the oven at $130^{\circ} \mathrm{C}$ for $1 \mathrm{~h}$ and the loss in weight was noted down using the following equations: 
M.C. $(\%$, w.b. $)=\frac{\mathrm{w}_{1}-\mathrm{W}_{2}}{\mathrm{w}_{1}} \times 100$

$\mathrm{W}_{1}=$ Weight of original sample $\mathrm{W}_{2}=$ Weight of dry sample

\section{Mechanical properties}

The force required to initiate the seed rupture for loading along the thickness was determined at various moisture contents with the help of a Texture Analyzer. For this purpose Canola seed was taken and was placed under a load cell. The maximum load which a material could bear was recorded and the graph of force required to cause the rupture of the seed was plotted on the monitor.

\section{Quantification of oil content in intact seeds}

The initial oil content of fresh Canola seeds was determined by using Newport Analyzer (Model MKIIIA) with a standard sample (4 g seeds with a known oil content) and the read out value was brought at the desired oil per cent by operating the instrument at the following conditions: $\mathrm{Rf}$ level $=100 \mu \mathrm{Amp}$; Integration time $=32$ secs. Weighed the dried seeds of the unknown sample and read the value of the oil content. This directly gave the oil per cent in seeds.

\section{Oil expression}

For oil extraction with the expeller, $200 \mathrm{~g}$ of seed sample was weighed with the help of a weighing balance. Calculated amounts of water were mixed with samples to increase their moisture content to the desired levels. The mixture was then allowed to equilibrate in low density plastic bags and kept at a room temperature for about 24-30 h. This resulted in four levels of moisture content; 8.4, 12.0, 16.0 , and $20 \%$ on wet basis. The oil recovery was then observed from the conditioned seeds using the expeller.

\section{Feed rate and moisture content}

The hopper opening was fixed for the seed throughout the experiment. The feed rate was kept fixed to $200 \mathrm{~g}$ sample. It took about 2-3 minutes to complete a batch of $200 \mathrm{~g}$ of seed. This resulted in an average crushing capacity of about $4.5 \mathrm{~kg} / \mathrm{h}$. The moisture content was an important parameter that affects the oil recovery significantly. The initial moisture content was measured as per A.S.A.E. standard (A.S.A.E, 1975).

\section{Press die clearance and screw rotational speed}

The effect of different die clearances and screw speeds was observed on response factors of Canola seeds. For this purpose three die clearances viz.; $4 \mathrm{~mm}, 5 \mathrm{~mm}$ and $6 \mathrm{~mm}$ were selected and four rotational speeds of screw viz.; $140 \mathrm{rpm}, 186 \mathrm{rpm}, 230 \mathrm{rpm}$ and $272 \mathrm{rpm}$ were selected.

\section{Heating treatment}

The expression machine was allowed to heat up to the desired temperature and duration with the help of a metal heater as shown in Figure 1. The conditioned samples were then fed to the feed hopper. The recovered crude oil after crushing was collected in a glass beaker and was measured with the help of a measuring cylinder. The crude oil was then transferred to the glass jar for nearly about 48 $\mathrm{h}$ to ensure the complete settlement of the meal at the bottom. The subsequent oil cake was recovered from the die opening.

\section{Per cent oil yield and extraction efficiency}

The per cent yield of the oil recovered was determined by employing the use of the following equations (Fasina and Ajibola 1989): 
The per cent oil yield $(\mathrm{Y})=\frac{\mathrm{w}_{1}-\mathrm{w}_{2}}{\mathrm{w}_{1}} \times 100$

Extraction Efficiency $(E)=\frac{\mathrm{w}_{1}-\mathrm{w}_{2}}{\mathrm{Z} \mathrm{W}} \times 100$

Where, $\mathrm{W}_{1}=$ weight of unexpressed sampleW $\mathrm{W}_{2}=$ weight of expressed sample

$\mathrm{Z}=$ initial oil content in the seeds

\section{Oil filtration}

The oil filtration process was carried out to recover the meal from the expressed crude oil. The oil was filtered using a fine muslin cloth of good quality. It took about 18-20 hours to complete the filtration of one set of the extracted oil.

\section{Residual oil in cake}

For residual oil analysis in cake, the dry cake was finely grounded using a pestle and mortar. About five gram of grounded cake in a powdered form was taken and transferred to the extracting thimble made of Whatman No.1 filter paper in a soxhlet apparatus. This was fitted in a condenser. About $250 \mathrm{ml}$ of pure n-hexane was taken in round flask which was fitted to a condenser. Three sets of such condensers were taken and were placed on an electric heater. The temperature of boiling was kept at $35{ }^{\circ} \mathrm{C}$ to allow the hexane to evaporate from the flask. A regular supply of fresh water was given to each condenser to immediately cool the condensers from hot hexane vapors. The flasks were then washed with redistilled hexane so that no oil particles were left in the flask and this mixture of oil and hexane was added to the beakers containing the filtrate. This mixture in the beaker was further heated on a heater at 25$30^{\circ} \mathrm{C}$ till all the hexane could evaporate. The left over oil in the beaker was then weighed and the percentage of oil recovered from the cake sample was calculated.

\section{Residual oil in meal}

After the oil filtration process, meal sample was recovered from the cloth and dried in an oven at $120^{\circ} \mathrm{C}$ for 5 to $6 \mathrm{~h}$ to allow the moisture to evaporate from the meal and the meal could become semi solid. About 1.5 to $2.0 \mathrm{~g}$ meal sample was taken in a thimble and the same procedure was followed for determination of residual oil in meal like which was followed for cake oil determination.

\section{Acid number determination of fats and oils} (A.O.A.C 1980)

Acid number may be defined as milligrams of Potassium Hydroxide required for neutralizing the free fatty acid present in $1 \mathrm{~g}$ of oil.

Principle: The free fatty acids present can be titrated and quantified by $\mathrm{KOH}$.

\section{Reagent}

i)

ii) $\quad 0.1 \%$ phenolphthalein

iii) $\quad$ N/10 Potassium Hydroxide

Procedure: Added about $25 \mathrm{ml}$ of $95 \%$ alcohol in a $250 \mathrm{ml}$ conical flask. Titrated the alcohol with N/10 potassium hydroxide to faint pink colour using phenolphthalein as indicator. Pipetted out $4.0 \mathrm{ml}$ of oil into the conical flask. The titrate was heated and boiled and again titration was continued with N/10 potassium hydroxide to a faint pink colour.

Acid number $=$

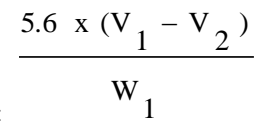


Where

$\mathrm{V}_{1}=$ volume in $\mathrm{ml}$ of potassium hydroxide solution required for blank

$\mathrm{V}_{2}=$ volume in $\mathrm{ml}$ of potassium hydroxide solution required for the sample

$\mathrm{W}_{1}=$ weight of sample in $\mathrm{g}$

Iodine value estimation (A.O.A.C 1980)

Iodine number is the number of grams of iodine taken up by $100 \mathrm{~g}$ of fat.

\section{Principle}

The double bonds of unsaturated acids in glycerides undergo characteristic addition reaction with halogens. The amount of halogen absorbed by oils is directly proportional to the degree of unsaturated and hence index of its level. A known amount of oil is treated with ICI and unreacted ICI is titrated as $\mathrm{I}_{2}$ in the presence of $\mathrm{KI}$ against sodium thiosulfate using starch as indicator.

\section{Reagants}

i) Iodine monochloride solution (Wij's solution): dissolved separately $8.5 \mathrm{~g}$ of iodine and $7.8 \mathrm{~g}$ of iodine tetrachloride in glacial acetic acid. Mixed well and made the volume to 1 litre with glacial acetic acid. The solution was heated to $100^{\circ} \mathrm{C}$ for $20 \mathrm{~min}$ and was cooled.

ii) $10 \%$ potassium iodide

iii) Sodium thiosulfate $0.1 \mathrm{~N}$

iv) Starch indicator $1 \%$

v) Carbon tetrachloride

\section{Procedure}

Pipetted out $0.5 \mathrm{ml}$ of oil into $250 \mathrm{ml}$ conical flask. Added $10 \mathrm{ml}$ of carbon tetrachloride to it and shook well. To this added $25 \mathrm{ml}$ of Wij's iodine solution. Kept the flask in dark for $1 \mathrm{~h}$. After that added $10 \mathrm{ml}$ of $10 \% \mathrm{KI}$ solution. Titrated the liberated iodine with 0.1 $\mathrm{N}$ sodium thiosulfate using 1 per cent starch indicator. Endpoint was blue to colourless.

Iodine number $=\frac{12.7 \times(B-S)}{\mathrm{W}}$

Where

$\mathrm{B}=$ volume in $\mathrm{ml}$ of sodium thiosulfate solution required for blank

$\mathrm{S}=$ volume in $\mathrm{ml}$ of sodium thiosulfate solution required for the sample

$\mathrm{N}=$ normality of standard sodium thiosulfate solution and

$\mathrm{W}=$ weight of sample in $\mathrm{g}$.

Peroxide value estimation (A.O.A.C 1980)

\section{Principle}

The sample is dissolved in acetic acid: chloroform mixture and potassium iodide is added. Peroxide oxygen liberates iodine from $\mathrm{KI}$ which is titrated with thiosulfate.

\section{Reagents}

i) Acetic acid - chloroform solution mixed three volumes of acetic acid with two volumes of chloroform.

ii) Potassium iodide solution, saturated dissolved KI in freshly boiled double distilled water till excess solid remained. Store in the dark.

iii) Sodium thiosulfate $-0.01 \mathrm{~N}$

\section{Procedure}

$0.5 \mathrm{~g}$ of oil sample was taken in a $250 \mathrm{ml}$ conical flask. Added $30 \mathrm{ml}$ of acetic acid: chloroform solution to it and swirled to dissolve the sample. Added $0.5 \mathrm{ml}$ saturated potassium iodide solution it was then allowed to stand with occasional shaking for $1 \mathrm{~min}$ and then $30 \mathrm{ml}$ of water was added to it. The 
solution was slowly titrated with $0.01 \mathrm{~N}$ sodium thiosulfate with vigorous shaking until yellow color was almost gone. $0.5 \mathrm{ml}$ of $1 \%$ starch solution was added. The titration was continued, shaking vigorously to release all iodine from chloroform layer, until blue colour disappeared.

Peroxide value (milliequiv. Peroxide/kg sample $)=\frac{(\mathrm{S}-\mathrm{B}) \times \mathrm{N} \times 1000}{\text { Sample } \quad \text { weight } \quad(\mathrm{g})}$

Where

$\mathrm{S}=\mathrm{ml}$ of $0.01 \mathrm{~N} \mathrm{Na}_{2} \mathrm{~S}_{2} \mathrm{O}_{3}$ required by sample

$\mathrm{B}=\mathrm{ml}$ of $0.01 \mathrm{~N} \mathrm{Na}_{2} \mathrm{~S}_{2} \mathrm{O}_{3}$ required by blank

$\mathrm{N}=$ Normality of $\mathrm{Na}_{2} \mathrm{~S}_{2} \mathrm{O}_{3}$ solution

\section{Results and Discussion}

\section{Effect of moisture content on mechanical properties of Canola seeds}

The force required to initiate the seed rupture for loading along the thickness was determined at four levels moisture content ranging from $8.4 \%$ to $20 \%$ for GSC - 5 variety of Canola seeds. The trend showing the effect of increasing moisture content is shown in the Figure 2 to 5 . It could be inferred from the figures that with increasing moisture content from $8.4 \%$ to $20 \%$ the rupture force are decreasing steadily from $1.202 \mathrm{~kg}$ to $0.884 \mathrm{~kg}$. This might have resulted from the fact that Canola seeds have soft texture at high moisture content.

Olayanju and Lucas (2004) determined the mechanical properties of two sesame seed cultivars at moisture levels of $4.1,5.3$ and $7.7 \%$ w.b. The force required values increased with increase in moisture content. The mean values for all the parameters were higher for dehulled than for undehulled seeds. Similarly, Tavakoli et al (2009) stated in his study that the rupture energy of the grains increased in magnitude with an increase in moisture content, while rupture force decreased.

\section{Determination of oil quality parameters for GSC - 6 and GSC - 5 varieties of Canolseed oil}

The various quality parameters like acid number, iodine value, peroxide value of Canola seed oil at different levels of moisture content which are presented in Table 2. From the table it could be revealed that Canola oil with maximum acid value was more unsaturated with respect to others and contains more fatty acids. Furthermore the oil with the maximum iodine value and peroxide value were more unstable and more prone to rancidity due to oxidation.

As the moisture content increased the percent oil yield decreased because the seed became soft with absorption of moisture so less force was applied by screw on the seed due to which the seed slided along with the screw. Moisture acted as lubricant in the barrel which resulted in insufficient friction and reduced the level of compression and contributed to poor oil recovery.

\section{Optimization of operational parameters of screw press by response surface methodology of Canola seeds}

For the optimization of different operational parameters of screw press on oil recovery, residual oil in cake, residual oil in meal, the effect of three factors at four levels was studied using RSM design trial version 8.0.1. Box - Behnken design technique. The various factors were the moisture content $(8.4,12.2$, 16.0 and $20.0 \%)$, heating time $(4,8,12$ and $16 \mathrm{~min})$, die clearance $(4,5$ and $6 \mathrm{~mm})$ and screw speed (140, 186, 272 and $312 \mathrm{rpm})$. Each factor was assigned a higher and a lower value in a particular range and the response was analyzed. The results obtained after experimentation are shown in Table 4. 
The maximum expeller extraction efficiencies of $91.66 \%$ and $88.12 \%$ were observed at $5.81 \%$ moisture content, 10 mins heating time, $85^{\circ} \mathrm{C}$ heating temperature, $6 \mathrm{~mm}$ die clearance and 312 screw speed as shown in Table 3.

Mwithiga and Moriasi (2007) studied the yield characteristics during Mechanical Expression of preheated and grounded Soybean samples. Soybeans were extracted for oil by compressing a ground sample at various operating pressures, pressing durations and product bulk temperatures.

The oil yield from the various operations was measured and expressed as a percentage of the original mass of crushed seeds. It was found that the oil yields increased linearly with increase in pressure as the compression pressure was increased from 40 to $80 \mathrm{kgf} / \mathrm{m}^{2}$ and that oil yield also increased linearly with increase in the duration of pressing within the range of 6 to $12 \mathrm{~min}$. Oil yield also increased with the bulk temperature of the preheated oilseeds but reached a peak yield at about $75^{\circ} \mathrm{C}$ and then decreased with further increase in temperature of oilseeds Similar trends are also found in our research.

\section{Optimization of moisture content, heating time and heating temperature on the response}

\section{Variables for GSC - 5 of Canola seeds}

The multiple regression analysis was tested to fit the high order polynomial to the experimental combinations shown.

The value for determination coefficient $R^{2}$ was 0.9642 for oil recovery, 0.7320 for residual oil in cake, 0.9009 for residual oil in meal and 0.9751 for press rate as shown in Figs. 6-8. However correlation by ANOVA for oil recovery was found to be non- significant residual oil in meal and press rate had a good lack of fit but the correlation for residual oil in cake was not found to have a good fit and was found to be non-significant

The correlation between experimental verses actual results was found to be perfectly good for oil recovery, residual oil in cake and meal and press rate. The $3 \mathrm{D}$ surface plots for the four responses are shown in Figure 6-9. From the figures of $3 \mathrm{D}$ plots it was concluded that oil recovery was found to decrease with increasing moisture content because of sliding of the seeds along the rotating screw and less crushing force offered by the screw to the seeds at high moisture content. However oil recovery with respect to heating time was almost constant.

The residual oil in cake first decreased and then increased with increase in moisture content and increased with increase in heating time. The residual oil in meal decreased with increasing trend of moisture content and heating time. However the press rate decreased with increasing moisture content. But with increasing heating time it remained constant. The high heating temperture lead to decrease in oil yield because high temperature caused frequent choking of the barrel, changed the moisture content and structure of the seeds during heating process. The multiple regression analysis resulted the following equations:

\section{For Oil recovery}

$10.32+1.47 \mathrm{x}_{1}-57.24 \mathrm{x}_{2}-22.26 \mathrm{x}_{3}-20.58$ $\mathrm{x}_{4}-10.86 \mathrm{x}_{5}-5.93 \mathrm{x}_{1} \mathrm{x}_{2}-55.38 \mathrm{x}_{1} \mathrm{x}_{3}+2.22$ $\mathrm{x}_{1} \mathrm{x}_{4}+27.97 \mathrm{x}_{1} \mathrm{x}_{5}+12.15 \mathrm{x}_{2} \mathrm{x}_{3}-81.81 \mathrm{x}_{2} \mathrm{x}_{4}+$ $0.79 \mathrm{x}_{2} \mathrm{x}_{5}-68.66 \mathrm{x}_{3} \mathrm{x}_{4}+45.45 \mathrm{x}_{3} \mathrm{x}_{5}-13.12$ $\mathrm{x}_{4} \mathrm{X}_{5}+0.83 \mathrm{x}_{1}{ }^{2}-29.94 \mathrm{x}_{2}{ }^{2}-9.31 \mathrm{x}_{5}^{2}$.

Where

$\mathrm{x}_{1}=$ Moisture content 
$\mathrm{x}_{2}=$ Heating time

$\mathrm{x}_{3}=$ Heating temperature

$\mathrm{x}_{4}=$ Die clearance

$\mathrm{x}_{5}=$ Screw speed

For residual oil in cake

$0.23-0.10 \mathrm{x}_{1}-0.42 \mathrm{x}_{2}-0.073 \mathrm{x}_{3}-0.44 \mathrm{x}_{4}-$

$0.12 \mathrm{x}_{5}+0.23 \mathrm{x}_{1} \mathrm{x}_{2}-0.20 \mathrm{x}_{1} \mathrm{x}_{3}+0.37 \mathrm{x}_{1} \mathrm{x}_{4}+$

$0.11 \mathrm{x}_{1} \mathrm{x}_{5}-0.038 \mathrm{x}_{2} \mathrm{x}_{3}-0.16 \mathrm{x}_{2} \mathrm{x}_{4}-0.046$ $\mathrm{x}_{1} \mathrm{x}_{5}-0.48 \mathrm{x}_{3} \mathrm{x}_{4}+0.28 \mathrm{x}_{3} \mathrm{x}_{5}-0.16 \mathrm{x}_{4} \mathrm{x}_{5}+0.15$ $\mathrm{x}_{1}{ }^{2}+0.21 \mathrm{x}_{2}{ }^{2}-0.27 \mathrm{x}_{5}{ }^{2}$.

For residual oil in meal

$0.11+0.055 \mathrm{x}_{1}-1.49 \mathrm{x}_{2}-0.51 \mathrm{x}_{3}-0.65 \mathrm{x}_{4}-$ $0.29 \mathrm{x}_{5}-4.105 \mathrm{E}-003 \mathrm{x}_{1} \mathrm{x}_{2}-1.55 \mathrm{x}_{1} \mathrm{x}_{3}+0.31$ $\mathrm{x}_{1} \mathrm{x}_{4}+0.65 \mathrm{x}_{1} \mathrm{x}_{5}+0.42 \mathrm{x}_{2} \mathrm{x}_{3}-1.77 \mathrm{x}_{2} \mathrm{x}_{4}-$ $0.038 \mathrm{x}_{2} \mathrm{x}_{5}-2.22 \mathrm{x}_{3} \mathrm{x}_{4}+1.47 \mathrm{x}_{3} \mathrm{x}_{5}-0.34 \mathrm{x}_{4} \mathrm{x}_{5}$ $+0.054 \mathrm{x}_{1}^{2}-0.37 \mathrm{x}_{2}^{2}-0.31 \mathrm{x}_{5}^{2}$.

Table.1 Specifications of the oil expeller

\begin{tabular}{|l|c|}
\hline $\begin{array}{l}\text { Capacity in }[\mathrm{kg}] \text { of input material / hour (depending on type and Bulk of Density of } \\
\text { oil seed to be processed) }\end{array}$ & $3-5$ \\
\hline Electric Power of Drive Motor in [kW] & 1.1 \\
\hline Weight in [kg] (net only, without input material) & 80 \\
\hline Dimensions in [mm] & 680 \\
Length & 580 \\
Width & 600 \\
\hline Height & \\
\hline
\end{tabular}

Table.2 Quality parameters for GSC - 5 variety of Canola seeds oil

\begin{tabular}{|c|c|c|c|c|}
\hline $\begin{array}{c}\text { Moisture } \\
\text { Content } \\
(\% \text { w.b. })\end{array}$ & $\begin{array}{c}\text { Oil } \\
\text { yield } \\
(\boldsymbol{\%})\end{array}$ & $\begin{array}{c}\text { Acid } \\
\text { Number }\end{array}$ & $\begin{array}{c}\text { Iodine Value } \\
\left(\mathbf{g} \mathbf{I}_{\mathbf{2}} / \mathbf{1 0 0} \mathbf{g} \text { oil }\right)\end{array}$ & $\begin{array}{c}\text { Peroxide value } \\
\text { (meq O2/kg oil) }\end{array}$ \\
\hline 8.4 & 30.2 & 5.99 & 146.12 & 15.15 \\
\hline 8.4 & 30.0 & 4.98 & 139.47 & 9.81 \\
\hline 5.81 & 37.0 & 6.85 & 142.16 & 39.60 \\
\hline 16.0 & 23.5 & 8.39 & 139.57 & 20.60 \\
\hline 12.2 & 23.0 & 12.54 & 126.04 & 4.76 \\
\hline
\end{tabular}

Table.3 Maximum expeller extraction efficiencies at different operational parameters of Canola seeds

\begin{tabular}{|c|c|c|c|c|c|}
\hline $\begin{array}{c}\text { MC } \\
(\boldsymbol{\%} \text { w.b. })\end{array}$ & $\begin{array}{c}\text { Heating } \\
\text { Time (mins) }\end{array}$ & $\begin{array}{c}\text { Heating } \\
\text { Temp. }\left({ }^{\circ} \mathbf{C}\right)\end{array}$ & $\begin{array}{c}\text { Die } \\
\text { clearance }(\mathbf{m m})\end{array}$ & $\begin{array}{c}\text { Screw speed } \\
(\mathbf{R P M})\end{array}$ & $\begin{array}{c}\text { Extraction } \\
\text { efficiency }(\boldsymbol{\%})\end{array}$ \\
\hline $\mathbf{5 . 8 1}$ & 10 & 85 & 6 & 186 & $\mathbf{8 8 . 1 2}$ \\
\hline $\mathbf{1 2 . 2}$ & 16 & 59.77 & 5 & 230 & $\mathbf{7 8 . 6 5}$ \\
\hline $\mathbf{8 . 4}$ & 4 & 70 & 6 & 272 & $\mathbf{7 3 . 7 8}$ \\
\hline $\mathbf{8 . 4}$ & 16 & 70 & 6 & 140 & $\mathbf{7 3 . 1 7}$ \\
\hline $\mathbf{8 . 4}$ & $\mathbf{4}$ & $\mathbf{1 0 0}$ & $\mathbf{6}$ & $\mathbf{2 7 2}$ & $\mathbf{6 2 . 8 0}$ \\
\hline
\end{tabular}


Table.4 Oil extraction with various independent variables (Moisture Content, Heating Time, Heating Temperature) Canola seeds

\begin{tabular}{|c|c|c|c|c|c|c|c|c|c|c|c|}
\hline \multirow[t]{2}{*}{ Std } & Run & $\begin{array}{c}\text { Factor } \\
1\end{array}$ & $\begin{array}{c}\text { Factor } \\
2\end{array}$ & $\begin{array}{c}\text { Factor } \\
3\end{array}$ & $\begin{array}{c}\text { Factor } \\
4\end{array}$ & $\begin{array}{c}\text { Factor } \\
5\end{array}$ & $\begin{array}{c}\text { Response } \\
1\end{array}$ & $\begin{array}{c}\text { Response } \\
2\end{array}$ & $\begin{array}{c}\text { Response } \\
3\end{array}$ & $\begin{array}{c}\text { Response } \\
4\end{array}$ & $\begin{array}{c}\text { Response } \\
5\end{array}$ \\
\hline & & $\begin{array}{c}\text { MC } \\
(\% \text { w.b. })\end{array}$ & $\begin{array}{c}\text { Heating } \\
\text { time (min) }\end{array}$ & $\begin{array}{c}\text { Heating } \\
\text { temp }\left({ }^{\circ} \mathrm{C}\right)\end{array}$ & $\begin{array}{l}\text { Die clearance } \\
(\mathbf{m m})\end{array}$ & $\begin{array}{c}\text { Screw } \\
\text { speed (rpm) }\end{array}$ & $\begin{array}{l}\text { Oil yield } \\
(\%)\end{array}$ & $\begin{array}{c}\text { Extraction } \\
\text { Efficiency } \\
(\%)\end{array}$ & $\begin{array}{c}\text { Cake oil } \\
(\%)\end{array}$ & $\begin{array}{l}\text { Meal oil } \\
(\%)\end{array}$ & $\begin{array}{c}\text { Press rate } \\
(\mathrm{kg} / \mathrm{h})\end{array}$ \\
\hline 15 & 1 & 12.2 & 10 & 85 & 5 & 140 & 24.5 & 59.67 & 0.175 & 0.21 & 2.17 \\
\hline 40 & 2 & 12.2 & 10 & 85 & 4 & 272 & 9.5 & 23.17 & 0.2 & 0.345 & 1.71 \\
\hline 21 & 3 & 16 & 4 & 70 & 4 & 186 & 7.5 & 18.29 & 0.325 & 0.146 & 1.06 \\
\hline 4 & 4 & 18.59 & 10 & 85 & 6 & 140 & 1.5 & 3.6 & 0.525 & 0.024 & 1.14 \\
\hline 1 & 5 & 8.4 & 4 & 70 & 6 & 272 & 30.25 & 73.98 & 0.114 & 0.385 & 4.56 \\
\hline 26 & 6 & 16 & 16 & 70 & 6 & 272 & 4.11 & 10.10 & 0.112 & 0.209 & 1.41 \\
\hline 16 & 7 & 16 & 16 & 100 & 4 & 186 & 6.0 & 14.63 & 0.411 & 0.075 & 1.03 \\
\hline 23 & 8 & 8.4 & 4 & 100 & 6 & 272 & 25.75 & 62.80 & 0.042 & 0.114 & 4.76 \\
\hline 39 & 9 & 12.2 & 10 & 85 & 4 & 272 & 21.75 & 53.05 & 0.84 & 0.059 & 2.72 \\
\hline 13 & 10 & 8.4 & 16 & 100 & 5 & 186 & 12.75 & 31.09 & 0.27 & 0.112 & 2.22 \\
\hline 32 & 11 & 16 & 4 & 100 & 5 & 272 & 8.5 & 20.73 & 0.48 & 0.205 & 1.49 \\
\hline 47 & 12 & 12.2 & 10 & 85 & 5 & 186 & 25.25 & 61.58 & 0.35 & 0.294 & 1.81 \\
\hline 50 & 13 & 12.2 & 10 & 59.77 & 5 & 230 & 32.25 & 78.65 & 0.205 & 0.226 & 2.74 \\
\hline 38 & 14 & 12.2 & 10 & 110.23 & 4 & 140 & 8.0 & 19.51 & 0.64 & 0.304 & 1.14 \\
\hline 27 & 15 & 8.4 & 16 & 70 & 6 & 140 & 30.0 & 73.17 & 0.101 & 0.64 & 2.38 \\
\hline 41 & 16 & 12.2 & 10 & 85 & 5 & 230 & 17.5 & 42.68 & 0.27 & 0.094 & 1.94 \\
\hline 45 & 17 & 12.2 & 20.09 & 85 & 4 & 272 & 18.86 & 46.00 & 0.326 & 0.138 & 2.58 \\
\hline 35 & 18 & 5.81 & 10 & 85 & 6 & 186 & 37.0 & 88.12 & 0.117 & 0.048 & 2.86 \\
\hline 48 & 19 & 12.2 & 20.09 & 85 & 4 & 140 & 12.75 & 31.09 & 0.34 & 0.112 & 1.48 \\
\hline 43 & 20 & 12.2 & 10 & 85 & 4 & 140 & 11.5 & 56.09 & 0.417 & 0.08 & 1.75 \\
\hline
\end{tabular}


Fig.1 Metal heater to provide heating treatment to the expeller

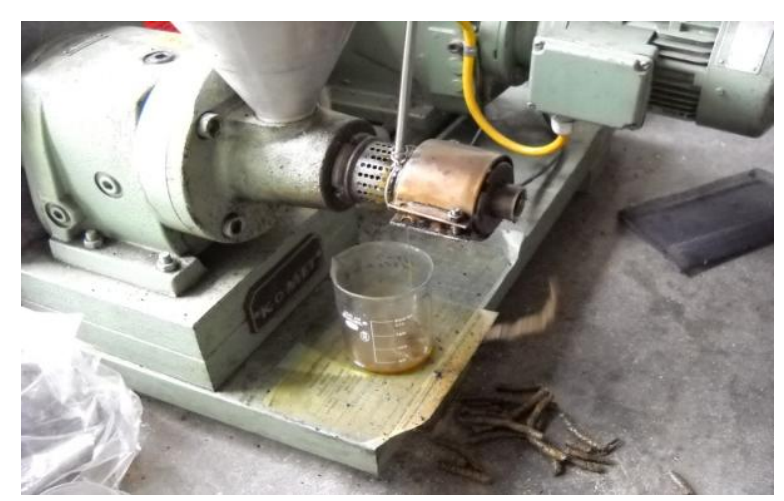

Fig.2 Effect of rupture force on GSC - 5 Canola seed at 8.4\% moisture content

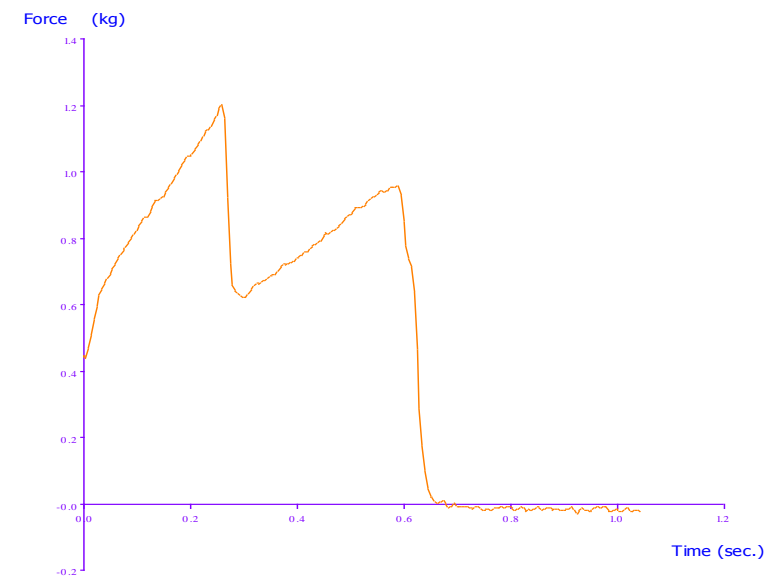

Fig.3 Effect of rupture force on GSC - 5 Canola seed at $12.2 \%$ moisture content

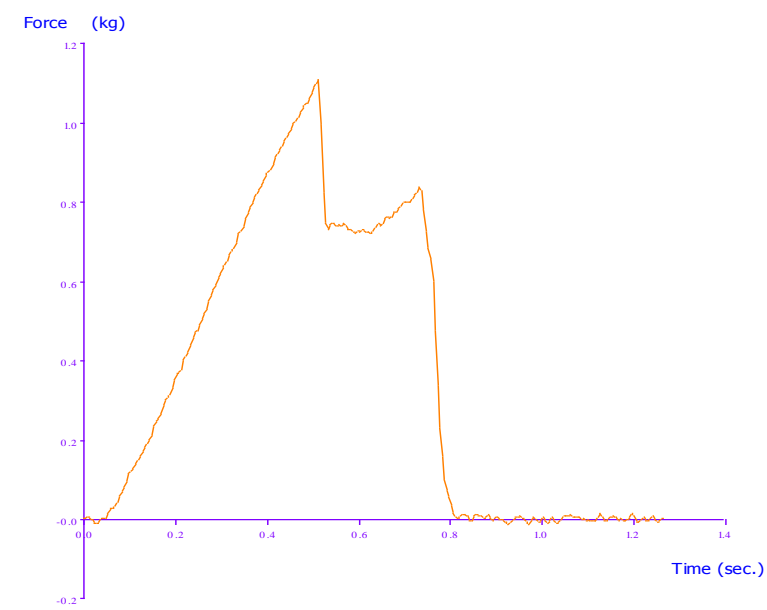


Fig.4 Effect of rupture force on GSC - 5 Canola seed at 16\% moisture content

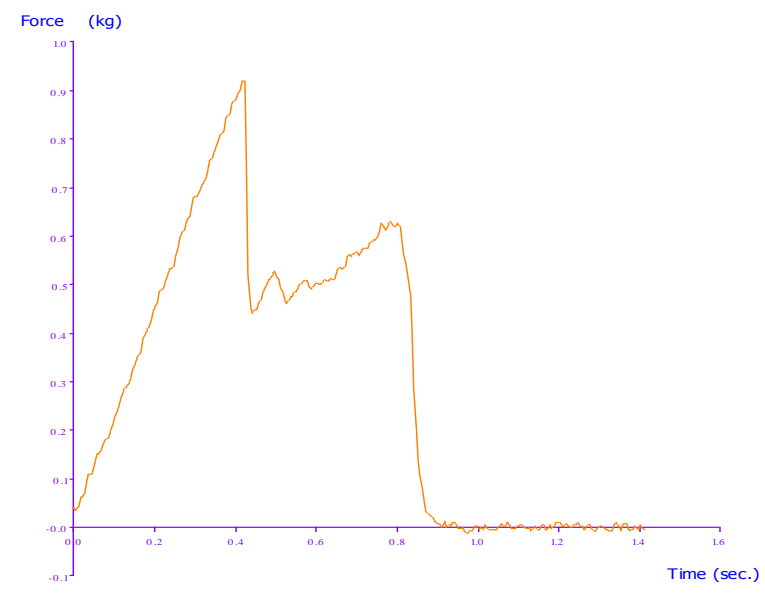

Fig.5 Effect of rupture force on GSC - 5 Canola seed at 20\% moisture content

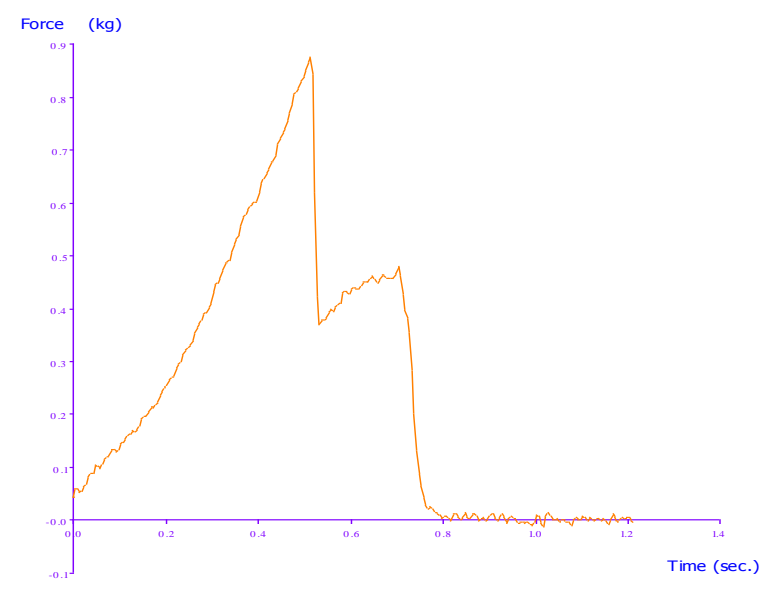

Fig.6 Surface plot for moisture content and heating time on response of oil recovery

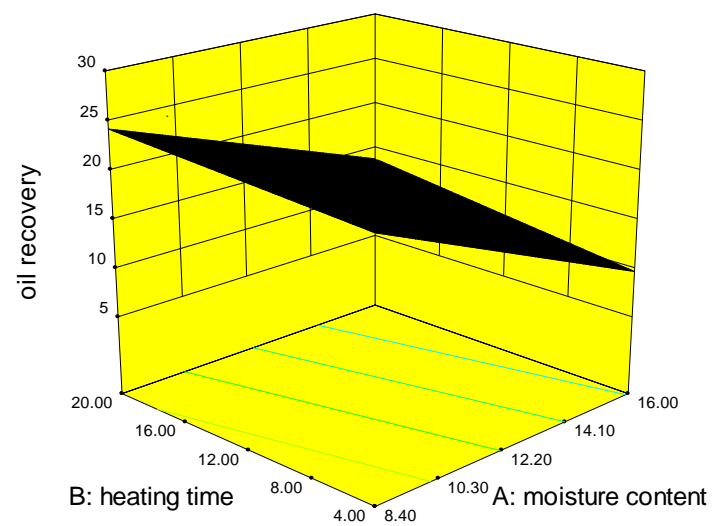


Fig.7 Surface plot for moisture content and heating time on response of residual oil in cake

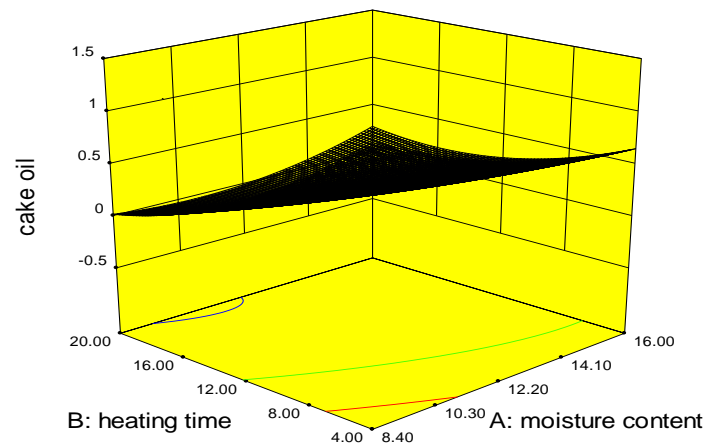

Fig.8 Surface plot for moisture content and heating time on response of residual oil in meal

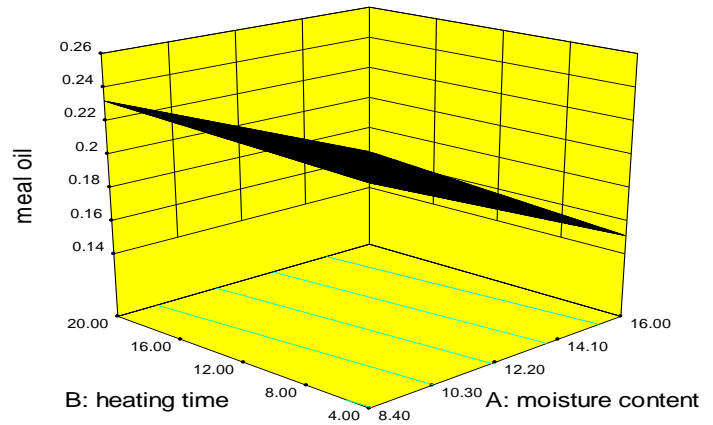

Fig.9 Surface plot for moisture content and heating time on response of press rate

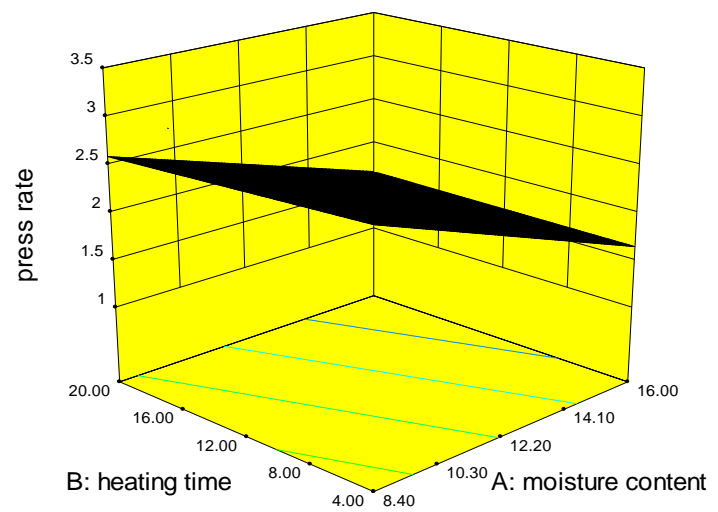

\section{For press rate}

$0.89+0.16 \mathrm{x}_{1}-4.86 \mathrm{x}_{2}-1.93 \mathrm{x}_{3}-1.76 \mathrm{x}_{4}+$ $0.23 \mathrm{x}_{5}-2.38 \mathrm{x}_{1} \mathrm{x}_{2}-5.89 \mathrm{x}_{1} \mathrm{x}_{3}-0.37 \mathrm{x}_{1} \mathrm{x}_{4}+$ $1.56 \mathrm{x}_{1} \mathrm{x}_{5}+1.84 \mathrm{x}_{2} \mathrm{x}_{3}-8.43 \mathrm{x}_{2} \mathrm{x}_{4}+0.24 \mathrm{x}_{2} \mathrm{x}_{5}-$ $7.29 \mathrm{x}_{3} \mathrm{x}_{4}+5.26 \mathrm{x}_{2} \mathrm{x}_{5}-0.069 \mathrm{x} 4 \mathrm{x} 5+0.19 \mathrm{x}_{1}^{2}-$ $4.64 \mathrm{x}_{2}^{2}+0.52 \mathrm{x}_{5}^{2}$.
From the above figure it is learned that with increase in moisture there is decrease in oil yield because moisture acted as lubricant in the barrel which resulted in insufficient friction and reduced level of compression hence contributed to poor oil recovery. 
In conclusion, the rupture force decreased with the increase in moisture content from $8.4 \%$ to $20 \%$ (wet basis).

The acid number, iodine value and peroxide value was found minimum at $8.4 \%$ moisture content and without any treatment. The constants for oil recovery model were found as $10.32,1.47,57.24,22.26,20.58,10.86,5.93$, $55.38,2.22,27.97,12.15,81.81,0.79,68.66$, $45.45,13.12,0.83,29.94$ and 9.31 for GSC-5 variety of Canola seeds. Effect of independent variables i.e. moisture content, heating time and heating temperature on oil recovery and press rate for GSC-6 variety were found significant however the effect of the independent variables on residual oil in cake was found nonsignificant whereas the effect of independent variables i.e. moisture content, heating time and heating temperature on oil recovery and press rate and residual oil in cake were found nonsignificant.

The maximum extraction efficiencies of $88.12 \%$ were observed at $5.81 \%$ moisture content, 10 mins heating time and $85^{\circ} \mathrm{C}$ heating temperature.

\section{References}

AkinosoR ,Raji A O and Igbeka J C (2008) Effects of Compressive Stress, Feeding Rate and Speed of Rotation on Palm Kernel Oil Yield. Department of Food Technology, Faculty of Technology, University of Ibadan Nigeria.

Anonymous (2007) Statistical Abstract of Punjab.

Boutin O and Badens E (2009) Extraction from oleaginous seeds using supercritical $\mathrm{CO}_{2}$ experimental design and products quality. J Food Engg 92:396-402.

Mrema G C and McNulty P B (1985) Mathematical models of mechanical oil expression from oil seeds. J Agric Engg Res 31:361-70.

Fasina O Oand Ajibola O O (1989) Mechanical expression of oil from conophor nut (Tetracarpidium conophorum) J Agri Engg Res 44:275-87.

Mwithiga G and Moriasi L (2007) A study on yield characteristics during mechanical oil extraction of preheated and ground soybeans. J App Sci and Res 3:1146-51.

Olayanju T M A and Lucas E B (2004) Mechanical behaviour of two beniseed (Sesamum indicum L.) cutivars under compression loading. J Food SciTechnol, 41:686-89.

PathakB S, Singh A, Singh D and Verma R N (1988) Mechanicaloil extraction. J Am Oil ChemSoc60:211-13.

Sivakumaran K, Goodrum W and Bradley A (1985) Expeller optimization for peanut oil production. Trans ASAE 85:316-20.

Srikantha P V R (1980) A search for an appropriate technique for village industry. AIDA, Lucknow Publications. pp 11-15.

Tavakoli H, Rajabipour A and Mohtasebi S S (2009) Moisture dependent some engineering properties of soybean grains. Agricultural Engineering International: the CIGR Ejournal. Manuscript 1110.Vol. XI. February, 2009.

Vadke V S and Sosulski F W (1988) Mechanics of Oil Expression from Canola. J Am Oil ChemSoc65:261-68. http://www.fcamin. nic.in/dpfd.

\section{How to cite this article:}

Gagandeep Singh, A.K. Singh and Pawanpreet Singh. 2019. Effect of Moisture Content on the Mechanical Oil Extraction of Canola Seeds. Int.J.Curr.Microbiol.App.Sci. 8(03): 965-977. doi: https://doi.org/10.20546/ijcmas.2019.803.116 